\title{
IDENTITAS ORGANISASI: EKSPLORASI TERHADAP DIMENSI DAN MAKNANYA BAGI PERUBAHAN ORGANISASI
}

\author{
Fathul Himam \\ Fakultas Psikologi Universitas Gadjah Mada Yogyakarta \\ e-mail: fathulhimam@yahoo.com
}

\begin{abstract}
This phenomenological study was aimed to understand and to explore how organization identity emerged when it faces with change and development. Based on this understanding, the dynamics and meaning of the new emerging identity was examined, especially in term of how the organization identity functions in dealing with changing environments. Five organizations that experienced and dealt with changing situations were involved within this study. The organizations involved in this study were ranged from educational institutions that developed new core businesses, mining factories that did rightsizing of their organization structures, and hotel businesses that developed their services quality, from two-star to four-star hotel. In-depth interviews were applied to organizations' decision makers who experienced the processs of developing strategies to deal with change of each organization. The results showed that new identity, the mechanism within the self of the organization, that led to new respect and dignity emerged. New themes were reconstructed and they led to new-emerging organization identity: (1) be more discipline with tighter rules and regulations; (2) be integrated and interconnected to all possible resources; (3) be more flexible, learning hard; and (4) self dignity and respect by developing quality assurance.
\end{abstract}

Keywords: phenomenological study, organization identity, organization change and development, in-depth interview

\begin{abstract}
Abstrak
Penelitian dengan menggunakan perspektif fenomenologis ini ditujukan untuk memahami bagaimana dimensi dan makna identitas organisasi yang sedang mengalami perubahan. Melalui pemahaman ini digali secara lebih mendalam bagaimana dinamika organisasi dalam memahami dan memaknai perkembangan identitas dirinya dalam konteks perubahan lingkungan. Lima organisasi yang sedang mengalami proses perubahan dilibatkan dalam penelitian ini. Organisasiorganisasi yang diteliti terdiri atas institusi pendidikan yang sedang mengembangkan bisnis atau aktivitas initinya, perusahaan pertambangan yang melakukan proses rightsizing, dan organisasi yang berkecimpung di bidang perhotelan yang tengah mengembangkan kualitas layanannya; dari bintang dua menuju ke kualitas layanan hotel bintang empat. In-depth interview digunakan pada para pengambil keputusan dalam organisasi yang mengalami langsung proses pengembangan strategi organisasi dalam menghadapi perubahan. Hasilnya menunjukkan bahwa orgnisasi membangun dan mengembangkan identitas baru, yang merupakan mekanisme yang berkembang dalam 'diri' organisasi, yang mengarah pada tema new respect and dignity. Identitas baru ini meliputi: (1) disiplin dengan membangun aturan dan regulasi yang lebih ketat; (2) terintegrasi dan terkoneksi dengan semua sumber daya yang relevan; (3) lebih lentur, dan belajar lebih keras; dan (4) self dignity and respect melalui upaya mengembangkanquality assurance yang efektif.
\end{abstract}

Kata kunci: perspektif fenomenologis, identitas organisasi, perubahan organisasi

\section{PENDAHULUAN}

Pada beberapa dekade terakhir ini, dunia organisasi difahami oleh para ahli sedang mengalami perubahan yang sangat signifikan dan dinamis (Ashkenas et al., 1995; Cummings \& Worley, 2005; Dhalla, 2007). Dapat dikata- 
kan bahwa cara organisasi mengembangkan dirinya sudah mengalami perubahan bentuk yang sangat kompleks dan dinamis (Himam, 2002; Dhalla, 2007). Kompleksitas perubahan yang terjadi sangatlah eksponensial, mengarah pada "the heart of what the organization believes about itself and how it behaves" (Clute et al., 1999, p. 24). Banyak organisasi yang terpaksa harus merespon perubahan tersebut sampai pada tataran inti struktur dan prosesnya (Fried et al., 2003) sehingga jati diri organisasi mengalami perubahan yang sangat mendasar (Bindle \& Salancik, 1999).

Salah satu aspek yang mendorong terjadinya perubahan ini adalah pesatnya perkembangan penggunanan teknologi informasi dan komunikasi dalam dunia manajemen organisasi. Dapat dikatakan bahwa teknologi informasi dan komunikasi membuat pola interaksi antar organisasi menjadi bersifat global, "boundaryless", menembus batasan jarak, waktu, dan letak geografis (Ashkenas et al., 1995). Jelas bahwa kondisi yang dihadapi organisasi untuk dapat tumbuh dan berkembang memaksa organisasi untuk menyesuaikan identitasnya sejalan dengan tuntutan perubahan yang dihadapi. Orgasisasi yang berorientasi lokal mau tidak mau harus berubah menjadi organisasi yang sifatnya trans-nasional; demi mengatasi perubahan-perubahan tuntutan lingkungan yang sifatnya juga trans-nasional.

Permasalahannya adalah bagaimana identitas organisasi dapat berubah dan berkembang? Ke arah mana perubahan dan perkembangan tersebut seharusnya ditujukan? Dampak apa yang timbul akibat dari perubahan ini? Pertanyaan-pertanyaan ini nampak sangat menarik perhatian para ahli untuk menjawabnya secara mendalam. Hogg dan Ridgeway (2003) mencermatinya dari sisi pengertian identitas organisasi yang dikatakannya sebagai perkembangan dari konsep "self" pada tataran organisasi dan menjelaskan proses belajar sebagai determinan yang menyebabkan self berubah dan berkembang. Ahli lain, Sztompka (2000), berargumen bahwa esensi perubahan dan perkembangan identitas organisasi adalah perubahan budaya. Budaya, yang berisi nilainilai, aturan-aturan, simbol, makna, dan lainlain, pada dasarnya merupakan esensi dari identitas organisasi. Pendapat ini didukung oleh kajian yang dilakukan oleh Markoczv (2000) yag membahas mengenai masalah budaya dan perubahan strategis organisasi.

Dari hasil kajian para ahli tersebut, dapat disimpulkan bahwa identitas organisasi merupakan tema yang masih membuka peluang yang luas untuk dikembangkan penelaahannya secara lebih mendalam. Hasil telaah ini difahami mampu menjawab seputar apa yang terjadi pada organisasi bila organisasi harus merestrukturisasi dirinya karena tuntutan perubahan lingkungan yang harus dihadapi secara strategis.

\section{Pertanyaan Penelitian}

Bagaimanakah dinamika perkembangan makna identitas organisasi pada organisasi-organisasi yang sedang mengalami perubahan karena tuntutan lingkungan?

\section{KAJIAN PUSTAKA}

Dari beberapa teori yang dikembangkan para ahli, nampak bahwa kajian terhadap isu identitas organisasi merupakan pengembangan pemahaman dari teori tentang self (Mead, 2004) serta teori social identity (Ashforth \& Mael, 2004). Organisasi dimetaforakan sebagai "individu" atau "entitas sosial" yang identitasnya dapat tumbuh dan berkembang sejalan dengan perkembangan interaksinya dengan lingkungan sekitar yang relevan dan mempunyai nilai strategis yang bermakna.

Perkembangan self, menurut Mead (2004), merupakan proses perkembangan sikap sebagai akibat dari proses interaksi sosial. Reaksi "individual self" pada esensinya merupakan proses modifikasi dan kodifikasi perilaku akibat dari responnya terhadap pengalaman yang dialami organisasi dalam konteks situasi sosial tersebut. Organisasi tidak hanya menyesuaikan self-nya terhadap sikap organisasi lain terhadap dirinya, tapi ia juga berusaha mempengaruhi sikap organisasi lain itu. Proses modifikasi self akan terjadi bila organisasi memahami pengalaman interaksinya sebagai satu hal yang penting, bermakna, dan menjadi perhatian utamanya.

Teori identitas sosial menjelaskan bahwa "individu organisasi" mempunyai kecenderungan yang kuat untuk mengklasifikasikan dirinya dan organisasi lain ke dalam berbagai jenis kategori sosial, seperti keanggotaan dalam suatu aliansi organisasi, afiliasi religi, orientasi terhadap isu-isu jender, kelompok 
"usia organisasi", dan sejenisnya (Ashford \& Mael, 2004). Proses kategorisasi ini dapat berfungsi sebagai alat yang digunakan organisasi untuk memahami organisasi lain; atau sebagai sarana yang digunakan organisasi untuk memahami dirinya dalam konteks interaksi "sosialnya". Hogg and Ridgeway (2003) secara eksplisit menyatakan bahwa identitas sosial pada dasarnya merupakan definisi evaluatif terhadap atribut sosialnya, atau merupakan collective self. Identitas sosial berkembang melalui proses belajar.

Pemahaman terakhir inilah yang kemudian digunakan sebagai dasar untuk menjelaskan fenomena identitas organisasi secara khusus. Esensi pertanyaan yang ingin dijawab berkenaan dengan pertanyaan-pertanyaan yang berhubungan dengan identitas: "who are we?, what kind of business are in? what do we want to be? (Albert \& Whetten, 2004). Terdapat tiga kriteria yang digunakan untuk menjelaskan identitas organisasi: (1) "the criterion of claimed central character", sebagai kriteria yang merujuk pada esensi organisasi; (2) "the criterion of claimed distinctiveness", kriteria yang difahami sebagai faktor yang membedakan antara satu organisasi dengan organisasi yang lain; dan (3) "the criterion of claimed temporal continuity", yang merupakan kriteria yang menunjukkan tingkatan kesamaan dari organisasi.

Ahli lain memahami identitas organisasi serupa dengan citra diri organisasi, yang diartikan sebagai karakteristik organisasi yang sifatnya "central, enduring, and distinctive" (Gioia, et al., 2004). Identitas organisasi berkembang sebagai pengertian kolektif para anggota organisasi terhadap karakteristik organisasi yang sifatnya penting, relatif permanen, serta bersifat membedakan antara satu organisasi dengan organisasi yang lain. Pengertian mkolektif ini muncul sebagai interpretasi terhadap nilai-nilai yang berkembang dalam organisasi, dan merupakan hasil dari proses rekonstruksi sosial sebagai akibat dari proses interaksi sosial (Hatch \& Schultz, 2004; Dhalla, 2007). Benning (2000) berpendapat bahwa proses interaksi ini dapat diinterpretasikan sebagai satu sumber yang mampu memunculkan terjadinya perubahan yang harus direspon dengan secara strategis. Ketidakmampuan organisasi berperilaku strategis dalam menghadapi perubahan akan membuat organisasi harus mengalami krisis yang berkepanjangan, yang pada akhirnya akan berdampak pada jati diri organisasi. Secara skematik pengertian ini dapat dijelaskan pada Gambar 1.

Dari Gambar 1 dapat disimpulkan bahwa esensi dari perubahan identitas organisasi merupakan akibat dari bagaimana perubahan difahami dan diinterpretasi sehingga memunculkan kesadaran yang kuat untuk mengkaji ulang esensi identitas apakah masih berfungsi efektif dalam menghadapi krisis.

Lebih jauh lagi Hatch and Schultz (2004) menjelaskan bahwa identitas organisasi pada dasarnya merupakan cerminan dari citra organisasi, merupakan refleksi dari budaya organisasi, serta berfungsi meningkatkan efektivitas organisasi dalam menyesuaikan diri dengan tintutan lingkungan. Gaines-Ross (2008) menyebutnya sebagai corporate reputation, yang pengertiannya merujuk pada bagaimana kredibilitas organisasi di mata anggota organisasi maupun lingkungan organisasi.

Atas dasar kajian para ahli terhadap identitas organisasi, muncul dua pertanyaan besar yang belum terjawab secara memuaskan, yaitu: bagaimana dinamika pemahaman makna identitas organisasi dalam konteks adapdasi organisasi terhadap tuntutan perubahan dari lingkungannya? Dimensi-dimensi apakah yang terkandung dalam pengertian identitas organisasi pada konteks perubahan? Pertanyaan-pertanyaan inilah yang menjadi fokus kajian penelitian ini.

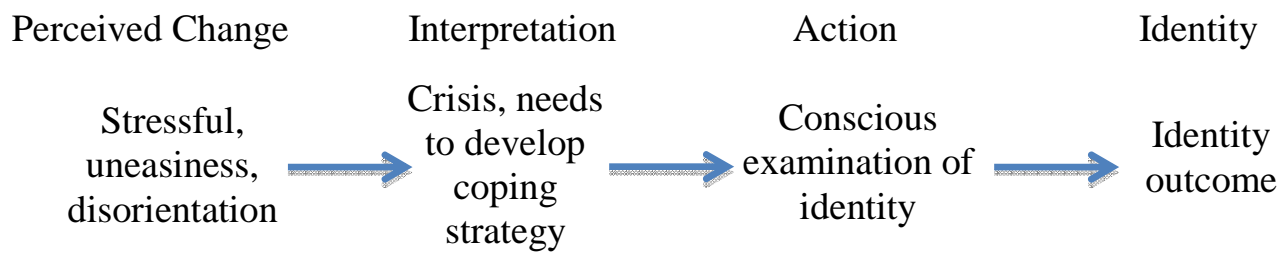

Gambar 1: Framework of Organization Identity Development (Benning, 2000) 


\section{RANCANGAN PENELITIAN}

Penelitian ini dirancang untuk mengeksplorasi dimensi serta makana identitas organisasi dalam konteks perubahan serta perkembangan yang sedang dihadapi oleh organisasi untuk diadaptasi dalam manajemen strategisnya. Walaupun level of analysis dari fenomena identitas yang diteliti adalah organisasi, tetapi yang dikaji adalah unsur terpenting yang menjadi esensi inti dari fenomena perilaku organisasi, yaitu pengalaman individu. Artinya, identitas organisasi difahami dan diinterpretasi sebagai fenomena agregat dari pengertian kolektif dari pengalaman para anggota organisasi terhadap pengalaman interaksinya yang dipandang penting dan bermakna (Hatch \& Schultz, 2004; Dhalla, 2007; Gaines-Ross, 2008).

Dengan pengertian ini, maka penelitian ini dirancang sesuai dengan perspektif fenomenologi (Moustakas, 1994; Creswell, 1998). Melalui perspektif ini akan digali bagaimana organisasi memahami pengalaman subyektifnya dalam menanggapi kondisi yang harus berubah, yang secara agregat akan membentuk pandangan serta pemahaman mereka terhadap esensi dimensi dan makna identitas organisasi secara keseluruhan. Lima organisasi yang sedang mengalami tuntutan perubahan dilibatkan dalam penelitian ini. Organisasi-organisasi yang diteliti terdiri atas institusi pendidikan yang sedang mengembangkan bisnis atau aktivitas intinya, perusahaan pertambangan yang melakukan proses rightsizing, dan organisasi yang berkecimpung di bidang perhotelan yang tengah mengembangkan kualitas layanannya; dari bintang dua menuju ke kualitas layanan hotel bintang empat. Masing-masing organisasi direpresentasikan oleh maksimal lima orang anggota organisasi yang mempunyai posisi sebagai pengambil keputusan dalam melakukan perubahan yang dijadikan sebagai sasaran kajian.

Adapun metode pengumpulan data penelitian menggunakan wawancara mendalam (Seidman, 1998). Proses analisis data penelitian akan mencakup beberapa proses inti, yaitu: epoche (upaya untuk mengesampingkan bias, prejudgment, serta pre-konsepsi tentang fenomena yang diteliti sehingga peneliti mampu melihat dan memahami fenomena ini sebagai hal yang baru), reduction (proses refleksi yang dilakukan peneliti untuk mereduksi bias yang menghambat dikembangkannya pemahaman yang sebenarnya tentang fenomena yang diteliti seperti apa adanya), imaginative variation (upaya yang dikembangkan peneliti untuk mencari kemungkinan esensi atau makna dasar dari fenomena yang diteliti melalui penggunaan imajinasi, pengembangan kerangka pemahaman yang bervariasi, serta upaya untuk memahami makna dari berbagai kemungkinan sudut pandang), serta synthesis of meaning and essences atau penyusunan satu pernyataan atau kesimpulan tentang esensi makna pengalaman dari fenomena yang dikaji (Moustakas, 1994). Hasil akhir dari penelitian ini berupa kategori dimensi serta makna dan atribut identitas organisasi sebagai ujud perilaku strategis dalam menghadapi perubahan.

\section{HASIL ANALISIS}

Kajian terhadap data penelitian menunjukkan bahwa perubahan dan ketidakpastian yang dialami organisasi dalam menghadapi tekanan dari lingkungannya menciptakan situasi kebingungan dalam menerapkan arah kebijakan dan strategi untuk menghadapinya, frustrasi, ketidakberdayaan, dan berkembangkan kebutuhan untuk menggunakan energi yang tinggi untuk berkonsentrasi menghadapi situasi yang serba berubah dan bersifat menekan. Dalam kondisi ini, organisasi bekerja keras untuk menjaga eksistensinya agar tidak 'larut' dalam proses perubahan yang sedang dihadapi. Bila tidak, fungsi keberadaannya dalam dunia bisnis, inti dari identitas atau 'self'nya, akan mempunyai kemungkinan yang tinggi untuk tereliminasi dalam percaturan bisnis dengan lingkungannya.

Identitas baru (i.e. the new self), dinamika yang terjadi dalam diri organisasi, menjadi satu keniscayaan yang harus dikembangkan. Identitas baru ini bergerak dan mengkristal menuju upaya untuk membangun citra organisasi yang bertemakan: terhormat dan terpandang (i.e. respect and dignity). Setelah dianalisis dengan lebih mendalam, ternyata tema ini mengarah pada tumbuhnya identitas organisasi baru yang struktur strategisnya mencakup: (1) disiplin; (2) mengintegrasikan seluruh sumber daya yang tersedia; (3) membangun fleksibilitas yang didasari oleh proses belajar yang berkesinambungan; yang kemudian akan 
bermuara pada (4) self dignity and respect. Identitas baru ini berfungsi sebagai strategic survival 'self' yang muncul dan berkembang sebagai konsekuensi dari proses adaptasi yang dilakukan oleh organisasi dalam menghadapi lingkungan yang mengancam, penuh resiko, serba tidak pasti dan bersifat menekan, serta penuh dengan tuntutan yang harus dipenuhi.

Pada waktu organisasi dipaksa harus berhadapan dengan resiko dan ketidakpastian, yang membuat mekanisme fungsional yang biasa dilakukan oleh organisasi menjadi tidak efektif dan menciptakan ketidakberdayaan, organisasi akan mengembangkan strategi konservatif yang berorientasi 'inward looking' sebagai strategi untuk menjaga tidak terjadinya pemborosan sumber daya melalui proses efisiensi. Perilaku ini menjelaskan makna tema (berperilaku) disiplin dan mengintegrasikan seluruh sumber daya. Strategi ini diarahkan untuk menjamin ketersediaan sumber daya dalam menghadapi ketidakpastian. Jelas bahwa perubahan yang menciptakan disharmoni dan ketidakberdayaan perlu dilawan dengan disiplin yang ketat dalam menggunakan sumber daya atas dasar pemahaman yang integral terhadap supply and demand sumber daya organisasi yang tersedia. Dengan berperilaku konservatif untuk kurun waktu tertentu, secara esensi organisasi sedang berupaya untuk membangun energi dan kapabilitas yang dapat digunakan untuk mempelajari dengan kritis kemungkinankemungkinan kesempatan yang dapat diraih dan dimanfaatkan. Dalam situasi ini, fleksibilitas dikembangkan, kemampuan untuk belajar menjadi berkembang. Organisasi mulai mampu memperoleh kemungkinan-kemungkan konsekuensi yang sifatnya rewarding sebagai konsekuensi dari kemampuan organisasi menerapkan strategi belajar yang efektif untuk memahami sekaligus memanfaatkan situasi yang serba berubah tersebut. Konsekuensinya, organisasi dapat mencipatkan citra yang porsitif, berupa dignity and respect, yang menjadi modal dasar bagi dikembangkannya pola interaksi organisasi dengan lingkungannya dengan lebih efektif dan efisien. Hasilnya akan bermuara pada terciptanya organizational high quality of performance yang kemudian akan berfungsi sebagai citra baru dari organisasi. Citra ini yang difahami dan digunakan oleh anggota organisasi sebagai referensi untuk mengembangkan fungsi peri laku dan peran mereka dalam menghadapi situasi yang serba berubah.

\section{PEMBAHASAN}

Tema yang tercakup dalam penelitian tentang identitas organisasi telah banyak mengundang perhatian dan perdebatan di kalangan para ahli organisasi dan manajemen stratejik (Whetten \& Godfrey, 1998). Konsepnya dapat dikatakan berakar pada teori identitas yang dikembangkan oleh Albert and Whetten (2004),

... identity as those characteristics of an organization which its members hold to be central, distinctive and enduring .

Konsep ini secara implisit menjelaskan bahwa identitas organisasi, bila berfungsi dengan efektif, akan mampu bersifat stabil, yang merepresentasikan collective cognitive construct bagi anggota organisasi yang sulit untuk diubah. Penelitian ini ternyata menemukan hal yang sebaliknya. Identitas organisasi, walaupun diakui digunakan sebagai referensi dasar dalam berperilaku, pada waktu harus dihadapkan pada kondisi lingkungan yang serba berubah menjadi bersifat tidak selamanya stabil. Identitas organisasi mempunyai kemungkinan untuk berubah dan berkembang, sejalan dengan perubahan dan perkembangan pengalaman baru yang sifatnya strategis yang dialami oleh organisasi. Hal ini sejalan dengan hasil temuan Himam (2002) yang menggarisbawahi peran inventing the future sebagai satu keniscayaan strategis yang dilakukan organisai untuk terus menerus menyesuaikan diri dengan tuntutan lingkungan.

Penelitian ini juga menjelaskan mengenai bagaimana organisasi bereaksi dalam menghadapi perubahan. Dalam situasi organisasi dipaksa oleh lingkungan untuk berubah, organisasi tidak serta merta berubah mengikuti tuntutan perubahan lingkungan, tetapi organisasi berupaya untuk menyelaraskan kondisi ekternal dengan kondisi internalnya melalui pengembangan disiplin diri dan penginte grasian sumber daya yang relevan. Baru kemudian organisasi beradaptasi dengan mengembangkan fungsi belajar yang menghasilkan fleksibilitas dalam bereksi. Proses ini kemudian berlanjut menuju proses dekonstruksi dan rekonstruksi identitas yang sifatnya kontinyu sehingga dapat tersimpulkan makna pola peri- 
laku yang tepat dalam menghadapi perubahan. Dalam proses dekonstrusi dan rekonstruksi, organisasi dipaksa untuk melakukan pengujian yang intensif terhadap efektivitas fungsi dan makna identitasnya, terutama dibandingkan dengan parameter future existence. Hal ini melibatkan proses dialog dan negosiasi dengan lingkungan. London dan kawan-kawan (2005) berpendapat bahwa identity negotiation terjadi bila organisasi memutuskan untuk bersikap terbuka, mau berbagi informasi mengenai dirinya. Keterbukaan ini ditujuan sebagai dasar untu membangun kemungkinan-kemungkinan positioning baru dalam hubungan organisasi dengan lingkungannya. Reformulasi serta pengembangan identitas baru mau tidak mau harus dilakukan bila negosiasi mengalami kegagalan.

\section{DAFTAR PUSTAKA}

Albert, S. \& DA. Whetten .2004. Organizational Identity. In Hatch, M.J. \& Schultz, M. (Eds., 2004). Organizational Identity: A Reader, New York: Oxford University Press.

Ashford, BE. \& F. Mael. 2004. Social Identity Theory and the Organization. In Hatch, M.J. \& Schultz, M. (Eds., 2004). Organizational Identity: A Reader, New York: Oxford University Press.

Ashkenas, R., D. Ulrich., T. Jick \& S. Kerr. 1995. The Boundaryless Organization. San Fransisco: Jossey-Bass.

Benning, ALW. 2000. Who We Are: Managing Organizational Identity During Strategic Change in Faith-Based Social Services Agency. Unpublished Dissertation, School of Management, Boston University, USA.

Brindle, MC., \& GR. Salancik. 1999. The Social Construction of an Institution: The Case of Brain Death and the Organ Transplant Industry. In Wagner III, J.A. (Ed., 1999). Advances in Qualitative Organizational Research, Stamford, Connecticut: JAI Press Inc.

Clute, PW., P Clute \& Associates. 1999. Change at an Oil Refinery: Toward the Creation of a Learning Organization. Human Resources Planning, 22(2), 24-
38.

Creswell, JW. 1998. Qualitative Inquiry and Research Design: Choosing Among Five Traditions. Thousand Oaks, California: SAGE Publications, Inc.

Cummings, TG. \& CG. Worley. 2005. Organizational Development ( ${ }^{\text {th }}$ ed.). New York: Thompson.

Dhalla, R. 2007. The Construction of Organizational Identity: Key Contributing External and Intra-Organizational Factors. Corporate Reputation Review, 10(4), 245-260.

Fried, Y., LH. Slowik, Z. Shperling, C. Franz, HA. Ben-David, N. Avital \& U. Yeverechyahu. 2003. The Moderating Effect of job Security on the Relation between Role Clarity and Job Performance: A Longitudinal field Study. Human Relations, 56(7), 787805.

Gaines-Ross, L. 2008. Corporate Reputation. New Jersey: John Wiley \& Sons, Inc.

Gioia, DA., M. Schultz \& KG. Corley. 2004. Organizational Identity, Image, and Adaptive Instability. In Hatch, M.J. \& Schultz, M. (Eds., 2004). Organizational Identity: A Reader, New York: Oxford University Press.

Hatch, MJ. \& M. Schultz. 2004. The Dynamics of Organizational Identity. In Hatch, MJ. \& M. Schultz (Eds., 2004). Organizational Identity: A Reader, New York: Oxford University Press.

Himam, F. 2002. Inventing The Future: A Meta-ethnographic Analysis Towards Understanding The Process of Individual and Organizational Adaptive Strategies to Change. Unpublished Doctoral Dissertation, University of Nebraska-Lincoln, Nebraska, USA.

Hogg, MA. \& CL. Ridgeway. 2003. Social Identity. Social Psychology Quarterly, 66(2), 97.

London, M., JT. Polzer \& H. Omoregie. 2005. Interpersonal Congruence, Transactive Memory, and Feedback Processes: An Integrative Model of Group Learning. 
Human Resource Development Review, 4 (2), 114-135.

Markoczv, L. 2000. National Culture and Strategic Change in Belief Formation. Journal of International Business Studies, 31(3), 427-442.

Mead, GH. 2004. The Self: The "I" and the "Me". In Hatch, M.J. \& Schultz, M. (Eds., 2004). Organizational Identity: A Reader, New York: Oxford University Press.
Moustakas, C. 1994. Phenomenological Research Methods. Thousand Oaks, California: SAGE Publications, Inc.

Seidman, I. 1998. Interviewing as Qualitative Research. New York: Teachers College Press.

Wthetten, DA. \& FC. Godfrey. Eds. 1998. Identity in Organization: Building Theory through Conversations, 128132, Thousand Oaks, CA: Sage Publications. 